\section{Research Square}

Preprints are preliminary reports that have not undergone peer review.

They should not be considered conclusive, used to inform clinical practice, or referenced by the media as validated information.

\title{
Gottfriedia Endophyticus sp. nov., a Novel Indole-Acetic Acid Producing Bacterium Isolated From The Roots of Rice Plant
}

\author{
Geeta Chhetri \\ Dongguk University-Seoul \\ Inhyup Kim \\ Dongguk University-Seoul \\ Taegun Seo ( $\nabla$ tseo@dongguk.edu ) \\ Dongguk Univesity https://orcid.org/0000-0001-9701-2806
}

\section{Research Article}

Keywords: Gottfriedia, Gottfriedia endophyticus, endospore, indole-acetic acid, tryptophan, biofertilizer

Posted Date: January 6th, 2022

DOI: https://doi.org/10.21203/rs.3.rs-1200826/v1

License: (c) (i) This work is licensed under a Creative Commons Attribution 4.0 International License. Read Full License 


\section{Abstract}

A Gram-stain-positive, aerobic, motile and rod-shaped bacterium, designated $R G 28^{\top}$, was isolated from the roots of rice plant collected from paddy fields in Goyang, South Korea. Cells of the strain were oxidase-negative but catalase-positive. Strain RG28 $8^{\top}$ was found to grow at $10-50^{\circ} \mathrm{C}$ (optimum, $25-30^{\circ} \mathrm{C}$ ), $\mathrm{pH} 5.0-10.0$ (optimum, $\mathrm{pH} 7.0$ ) and in $1.0-5.0 \%$ (w/v) $\mathrm{NaCl}$ (optimum, 0\%). The cell-wall peptidoglycan contained meso-diaminopimelic acid and the predominant menaquinones were MK-7 and MK-6. The predominant cellular fatty acids were $C_{16: 0}$, iso- $C_{15: 0}$ and anteiso- $C_{15: 0}$. The major polar lipids included phosphatidylethanolamine, diphosphatidylglycerol, phosphatidylglycerol, four unidentified aminophosphoglycolipids, four unidentified aminophospholipids, two unidentified glycolipids, one unidentified aminoglycolipid and four unidentified lipids. The genomic DNA G+C content was $33.5 \mathrm{~mol} \%$. Phylogenetic analysis based on 16S rRNA gene sequences showed that the strain was closely related to Gottfriedia acidiceleris CBD $119^{\top}$ (98.6\%), Gottfriedia solisilvae LMG $18422^{\top}(98.5 \%)$ and Gottfriedia Iuciferensis LMG $18422^{\top}(98.4 \%)$. The average nucleotide identity (ANI) and in silico DNA-DNA hybridization (isDDH) values between strain $\mathrm{RG}^{\top} 8^{\top}$ and type strains of Gottfriedia species were lower than the cut-offs ( $\geq 95-96 \%$ for ANI and $\geq 70 \%$ for isDDH) required to define a bacterial species. Meanwhile, the strain has the ability to produce indole-acetic acid $(40.5 \mu \mathrm{g} / \mathrm{mL})$. Phylogenetic, physiological and chemotaxonomic data suggested that strain $\mathrm{RG}_{2} 8^{\top}$ represented a novel species of the genus Gottfriedia, for which the name Gottfriedia endophyticus sp. nov. is proposed, with the type strain $\mathrm{RG}^{2} 8^{\top}\left(=\mathrm{KCTC} 43327^{\top}=\mathrm{TBRC}^{15151^{\top}}\right)$.

Repositories: The draft genome and 16S rRNA gene sequences of strain $\mathrm{RG}^{\top} 8^{\top}$ have been deposited in GenBank/EMBL/DDBJ under accession numbers JAGIYQ000000000 and MW386408 respectively.

\section{Introduction}

The genus Bacillus, containing 293 species and subspecies, was recently reclassified on the basis of phylogenomic and comparative genomic frameworks, and six genera, Cytobacillus, Peribacillus, Mesobacillus, MetabacillusNeobacillus, Metabacillus and Alkalihalobacillus, were separated from it, limiting Bacillus to only the members of the Subtilis and Cereus clades of species (Gupta et al. 2020). Members of Gottfriedia were transferred from the polyphyletic genus Bacillus, whose complicated interspecies taxonomy arose as a result of vague criteria used to assign novel bacteria into the genus (Jiang et al. 2021). The type species for this genus is Gottfriedia luciferensis (Logan et al. 2002). The genus Gottfriedia contains only three species with validly published names (https://lpsn.dsmz.de/genus/gottfriedia). Species of Gottfriedia have been isolated from soils and forensic specimen so far (Logan et al. 2002; Pan et al. 2017; Peak et al. 2007). Here, we present the isolation and description of a novel, indole-3-acetic acid (IAA) producing bacterium belonging to the genus Gottfriedia recovered from the roots of rice plants. The plant hormone IAA plays a role in the communication between host plant and microbes, including plant-associated microorganisms and endophytes but as well as plant pathogens (Rai et al. 2005; Vandeputte et al. 2005). In this study we also compared the amount of IAA produced by strain $\mathrm{RG}_{28}{ }^{\top}$ and other three close strains in the genus Gottfriedia.

\section{Materials And Methods}

\section{Isolation and ecology}

Samples from paddy field were collected near Dongguk University, Goyang, South Korea, (GPS coordinates of the sample collection site; $\left.37^{\circ} 40^{\prime} 26.4^{\prime \prime} \mathrm{N} 126^{\circ} 48^{\prime} 20.88^{\prime \prime} \mathrm{E}\right)$ for bacterial isolation as part of an ongoing study on the microbial diversity in our lab (Chhetri et al. 2019; Chhetri et al. 2020; Chhetri et al. 2021a; Chhetri et al. 2021b). Roots were gently washed with water to remove adhered soil and prepared for screening of novel isolates as described previously (Chhetri et al. 2021b). The root samples were surface-sterilized and after being dried in the hood and the surface sterilized samples were ground into powder by mortar and pestle. The macerated samples were serially diluted using $0.85 \% \mathrm{NaCl}$. Isolation 
was achieved using R2A agar (Difco) at $28^{\circ} \mathrm{C}$ for 1 week. A single colony chosen on the plates was purified by transferring to new R2A plates. Purified colonies were sent to Bionics (Daejeon, Republic of Korea) for 16S rRNA gene analysis. From the purified bacterial colonies, a novel strain of the genus was identified to be a member of Gottfriedia and was designated as RG28 ${ }^{\top}$. Purified colonies were cultured routinely on R2A at $30^{\circ} \mathrm{C}$ and preserved as a suspension in R2A broth with glycerol $(25 \%, \mathrm{v} / \mathrm{v})$ at $-80^{\circ} \mathrm{C}$.

\section{S rRNA gene sequence similarities and phylogenetic analysis}

The genomic DNA was extracted and PCR amplification and sequencing of 16S rRNA gene were performed as described previously (Kim et al. 2020). The 16S rRNA gene of the isolate was directly amplified by colony-PCR using the universal bacterial primers 27F, 518F, 805R and 1492R; PCR products were commercially sequenced (Solgent, Korea). EzBioCloud's Identify service (www.ezbiocloud.net/identify; Kim at al. 2012) was used to identify strain RG28 ${ }^{\top}$, and the 16S rRNA gene sequences of closely related type strains were retrieved. These sequences were aligned by using the CLUSTAL_X program (Thompson et al. 1997). Phylogenetic trees were reconstructed using the neighbour-joining (NJ), maximum-likelihood (ML), minimum-evolution (ME) and maximum-parsimony (MP) methods in the software package mega version 7.0 (Saitou et al. 1987; Felsentein et al. 1981; Rzhetsky et al. 1992; Fitch et al. 1971; Kumar et al. 2016). The robustness of the topologies for the phylogenetic trees was evaluated by bootstrap analysis of 1000 replications (Felsenstein et al. 1985).

\section{Genome sequencing, assembly and annotation}

Genomic DNA sequencing was performed at Macrogen on an Illumina Hiseq4000 system. A DNA library was prepared using the TruSeq Nano DNA kit. Raw reads filtered by FastQC and were assembled using SOAPdenovo v. 3.10.1 de novo assembler. After assembling the draft genome, the locations of protein genes were predicted and their functions were annotated. The average nucleotide identity (ANI) values between strain $\mathrm{RG}^{\mathrm{T}}{ }^{\top}$ and its phylogenetic neighbours were calculated using an ANI calculator (www.ezbiocloud.net/tools/ani) (Yoon et al. 2017). The estimated digital DNA-DNA hybridization $(\mathrm{dDDH})$ values were calculated using the Genome-to-Genome Distance Calculator (GGDC2.1,

http://ggdc.dsmz.de/distcalc2.php) (Meier-Kolthoff et al. 2013). The DNA G+C content of strain RG28 ${ }^{\top}$ was determined according to the genomic DNA sequences. Gene prediction and annotation were performed using the NCBI Prokaryotic Genome Annotation Pipeline (PGAP) (Tatusova et al. 2016). Comparisons of orthologous gene clusters among strain $\mathrm{RG}^{\top} 8^{\top}$ and other close strains were performed by using OrthoVenn2 (https://orthovenn2.bioinfotoolkits.net/home) (Xu et al. 2019). In order to strengthen the phylogenetic status and better characterize the relationships between the novel isolate and its other closely related species, phylogenomic trees were constructed based on the basis of an up-to-date bacterial 92 core gene set (UBCG) (Na et al. 2018). The secondary metabolic gene clusters were analysed with antiSMASH (version 2.0.2) (Blin et al. 2019).

\section{Phenotypic features}

Cells of $\mathrm{RG}^{\mathrm{T}} 8^{\mathrm{T}}$ grown on $\mathrm{R} 2 \mathrm{~A}$ at $30^{\circ} \mathrm{C}$ for three days were used for physiological and biochemical tests. Colony morphology was observed on R2A agar plates after incubation at $30^{\circ} \mathrm{C}$. Cell morphology and flagellum was examined by growing the cells for three days at $30^{\circ} \mathrm{C}$ using transmission electron microscopy (TEM) (LIBRA 120, Carl Zeiss, Germany). For the latter assessments, the cells were negatively stained with $1 \%(\mathrm{w} / \mathrm{v})$ phosphotungstic acid and, after air-drying, the grids were examined for cell morphology. Anaerobic growth on R2A medium was evaluated using the GasPack anaerobic system (BBL, Cockeysville, MD, USA). Formation of endospores was assessed with the malachite green stain after cell growth on R2A for 3 days. Oxygen absorber stripes (MITSUBISHI GAS CHEMICAL company) were used to remove oxygen. Growth at various temperatures $\left(4-55^{\circ} \mathrm{C}\right)$ was measured on R2A agar for ten days. Growth at various concentrations of $\mathrm{NaCl}(0-0.5$ and $1.0-10.0 \%$, at increments of $1.0 \%, \mathrm{w} / \mathrm{v})$ was tested in $\mathrm{R} 2 \mathrm{~A}$ medium at $\mathrm{pH} 7.0$ for 10 days at $30^{\circ} \mathrm{C}$. Growth experiments were performed on several media such as, Reasoner's 2agar (R2A), marine agar (MA), nutrient agar (NA), tryptic soy agar (TSA) and Luria-bertani agar (LB) at $30^{\circ} \mathrm{C}$ for seven days. The $\mathrm{pH}$ range for growth was determined by 
cultivation at $30^{\circ} \mathrm{C}$ in R2A broth adjusted to $\mathrm{pH} 4-10$ (at pH 1 unit intervals) before sterilization with citrate/ $\mathrm{NaH}_{2} \mathrm{PO} 4$ buffer ( $\mathrm{pH}$ 4.0-5.0), phosphate buffer ( $\mathrm{pH}$ 6.0-8.0) and Tris buffer ( $\mathrm{pH}$ 9.0-10.0) as described previously (Kim et al. 2020). The activities of catalase and oxidase and hydrolysis of casein, chitin, carboxymethyl-cellulose, starch and Tweens 20, 40, 60 and 80 were determined as described previously (Smibert et al. 1994). In addition, the strain RG28 ${ }^{\top}$ and reference strains were characterized biochemically using API 20NE and API ZYM strips (bioMérieux), according to the manufacturer's instructions. Acid production from carbon sources was tested using the API 50CH (bioMérieux) system.

\section{Chemotaxonomic analysis}

The cellular fatty acid profiles of strains $\mathrm{RG} 8^{\top}$ and its close strains were determined using cells from the third quadrants grown on R2A medium at $30^{\circ} \mathrm{C}$ for $48 \mathrm{~h}$. The cells were saponified, methylated and extracted using the standard MIDI (Sherlock Microbial Identification System, version 6.0B) protocol as described previously (Collins et al. 1981). Isoprenoid quinines were extracted with methanol/water and petroleum ether at $60-80^{\circ} \mathrm{C}$, evaporated under a vaccum. The sample was re-extracted with acetone and analysed by HPLC as described previously (Kuykendall et al. 1988). For peptidoglycan analysis, cells of strain RG28 ${ }^{\top}$ were grown in R2A broth on a rotator shaker for 4 days at $30^{\circ} \mathrm{C}$ and performed as described previously (Kim et al. 2019). Polar lipids were extracted and separated using two-dimensional TLC according to the method described previously (Minnikin et al. 1984). The solvent systems of the first and the second dimension were chloroform-methanol-water (64:27:5, by vol.) and chloroform-acetic acid-methanolwater (80:18:12:5, by vol.), respectively. To identify the specific moieties of lipids the following spraying methods were applied: $0.5 \%$ a-naphthol in methanol and water $(1: 1, \mathrm{v} / \mathrm{v})$ followed by spraying with $95 \%$ sulfuric acid for glycolipids; $0.25 \%$ ninhydrin in acetone for amino lipids; molybdenum blue reagent (Sigma) for phospholipids; and 5\% molybdatophosphoric acid hydrate (Merck) in ethanol for total lipids (Komagata et al. 1987).

\section{Indole acetic acid (IAA) production and quantification}

Strain $\mathrm{RG} 28^{\top}$ and all three reference strains were grown in R2A medium with or without $0.1 \%$ tryptophan at $30^{\circ} \mathrm{C}$ for 3 days. Cell culture was centrifuged at $6000 \mathrm{rpm}$ for $30 \mathrm{~min}$ after 3 days of incubation. Supernatant was reserved and $1 \mathrm{ml}$ was mixed with $2 \mathrm{ml}$ of Salkowski's reagent ( $2 \% 0.5 \mathrm{FeCl} 3$ in $35 \% \mathrm{HCLO} 4$ solution), then incubated at room temperature for 30 minutes. Reserved supernatant was spectrophotometrically assessed at $530 \mathrm{~nm}$. Indole production was indicated by color change into orange to pink. Result was compared with and without tryptophan (not shown).

\section{Results And Discussion}

\section{$16 S$ rRNA gene sequence similarities and\& phylogenetic analysis}

An almost full-length sequence of the $16 \mathrm{~S}$ rRNA gene (1484 bp) was determined for strain RG $^{2}{ }^{\top}$, which has been stored in the GenBank databases under the accession number MW386408. The full length of the 16S rRNA gene of strain RG28 ${ }^{T \&}$ showed the highest sequence similarity to G. acidiceleris CBD $119^{\top} \&$ (98.6\%), G. solisilvae LMG $18422^{\top}(98.5 \%)$ and G. Iuciferensis LMG $18422^{\top}$ (98.4\%). Sequence similarities to all other species of the genus Bacillus, Cytobacillus, Neobacillus, Sutcliffiella and Metabacillus were below 95.2\%. The NJ phylogenetic analysis revealed that strain RG28 ${ }^{\top}$

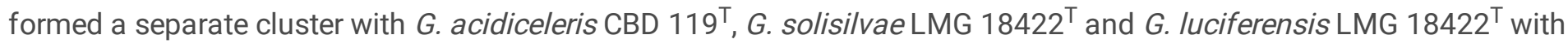
high topology\& which was also supported by the trees reconstructed using the ML, ME and MP methods (Fig. 1, Fig S1, Fig S2 and Fig S3). The position of strain $\mathrm{RG}_{2} 8^{\top}$ did not vary with the tree reconstruction method used. Reference strains Gottfriedia acidiceleris KEMB 1602-188 ${ }^{\top}$, G. luciferensis KEMB 7305-013 ${ }^{\top}$ and G. solisilvae DSM $100485^{\top}$ obtained from Korean Environmental Microorganisms Bank (KEMB) and Deutsche Sammlung von Mikroorganismen und Zellkulturen (DSMZ) were used for subsequent comparison. 


\section{Genome sequencing, assembly and annotation\&}

The draft genome of strain $\mathrm{RG}^{2} 8^{\top}$ was $4,081,222$ bp long with a $\mathrm{G}+\mathrm{C}$ content of $33.5 \mathrm{~mol} \%$ and consisted of 34 contigs. The N50 length was $362,561 \mathrm{bp}$. A total of 3,940 genes were predicted with 3,802 protein-coding genes and 15 RNAs (seven 5 S rRNAs, four 16S rRNAs, four 23S rRNAs), 73 tRNAs and three ncRNAs. The ANI value between strain RG28 ${ }^{\top}$ and \& G. acidiceleris KEMB 1602-188 ${ }^{\top}$, G. solisilvae DSM $100485^{\top}$ and $G$. luciferensis KEMB 7305-013 ${ }^{\top}$ were $74.7,74.8$ and $74.9 \%$, respectively, clearly below the recommended cut-off value of $95-96 \%$ for species identification (Goris et al. 2007). The estimated $\mathrm{dDDH}$ value between strain $\mathrm{RG}^{2} 8^{\top}$ and\& G. acidiceleris KEMB 1602-188 ${ }^{\top}$, G. solisilvae DSM $100485^{\top}$ and $G$. Iuciferensis KEMB $7305-013^{\top}$ were $21.6,21.8$ and $21.9 \%$, respectively, which was well below the $70 \%$ threshold described by Chun et al. (2018). These results indicated that strain RG28 ${ }^{\top}$ represents a novel species of the genus\& Gottfriedia.\& The overall comparison analysis result is displayed as Venn diagram in Fig. 2. A total of 2299 orthologous genes were shared among all the compared species, of which 79 were shared only between strain RG28 and\& G. acidiceleris KEMB 1602-188 ${ }^{\top}, 77$ between strain $\mathrm{RG}^{\top} 8^{\top}$ and \& G. solisilvae DSM $100485^{\top}$ and 71 between strain

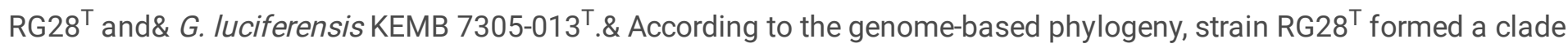
with\& G. acidiceleris KEMB $1602-188^{\top}$, G. solisilvae DSM $100485^{\top}$ and G. luciferensis KEMB $7305-013^{\top}$ in the genus\& Gottfriedia with bootstrap support of $92 \%$, confirming the topology determined by 16 S rRNA gene sequencing.

Furthermore, four\& Gottfriedia species formed a monophyletic cluster and were clearly separated from other species of the genus Bacillus, Neobacillus and Cytobacillus (Fig S4).\& AntiSMASH analysis results showed four gene clusters within the genome of strain\& $R G 28^{\top}$, namely two gene cluster for terpene, one gene cluster for thiopeptides and one gene cluster for linear azol (in) e-containing peptide (LAP). When the results of \& secondary metabolic gene clusters were compared between strain $R G 28^{\top}$ and its closest relatives, the gene cluster for thiopeptide was only found in strain $R G 28^{\top}$ which distinguish the novel isolates from its close relatives. In addition, large number of genes involve in sporulation, spore formation were also detected in the genome of strain $\mathrm{RG}^{\top} 8^{\top}$ (Table S1), which is consistent with our results showing the production of endospores.\& The genome of strain $\mathrm{RG}_{28}{ }^{\top}$ contained four genes related to tryptophan biosynthesis: tryptophan synthase subunit beta (trpB) (JAGIYQ010000010), tryptophan-tRNA ligase (trpS) (JAGIYQ010000003), tryptophan 2,3-dioxygenase (JAGIYQ010000006) and anthranilate synthase component I (JAGIYQ010000021)\& which indicates that strain $\mathrm{RG}_{28}{ }^{\top}$ could contribute to the plant growth-promoting activity in rice plants. When we compared the plant growth promoting rhizobacteria (PGPR) genes of strain $R G 28^{\top}$ with its close strains, interestingly the reference strains had more genes related to tryptophan biosynthesis. In addition, the reference strains had genes for siderophore and indole biosynthesis which were not found in the genome of strain $\mathrm{RG}^{\top} 8^{\top}$ (Table 2). These genomic features indicate that strain $\mathrm{RG}^{\mathrm{T}} \mathrm{S}^{\mathrm{T}}$ and its reference strains could be a PGPR candidate.

\section{Phenotypic features}

Strain $\mathrm{RG}_{28}^{\top}$ was Gram-stain-positive, catalase-positive and oxidase-negative. Colonies grown on R2A plates were circular, white, smooth and $1-3 \mathrm{~mm}$ in diameter after three days of culture. Cells of the isolate were motile with peritrichous flagella (Fig. S5). Cells were able to grow at $10-50^{\circ} \mathrm{C}$ and $\mathrm{pH} 5.0-10.0$, with optimal growth at $25-30^{\circ} \mathrm{C}$ and $\mathrm{pH}$ 7.0. The growth occured in $0-5 \% \mathrm{NaCl}(\mathrm{w} / \mathrm{v})$ with optimum $0 \%$. The strain showed no anaerobic growth on R2A plates. Endospores were produced at the termini in non-swollen sporangia (Fig. S6). Strain RG28 ${ }^{\top}$ grew well on R2A, NA, TSA and LB but grew only moderately on MA. Strain RG28 ${ }^{\top}$ was tolerant up to $5 \% \mathrm{NaCl}$, while\& G. solisilvae LMG $18422^{\top}$ tolerated to $4 \%, \&$ G. acidiceleris CBD $119^{\top \&}$ to $2 \%$ and \& G. luciferensis $\mathrm{LMG} 18422^{\top}$ to $1 \%$ of $\mathrm{NaCl}$ in culture media. Cell morphology, colony colour, presence of flagella, oxidase activity, temperature and $\mathrm{pH}$ range for growth, differentiates the strain $R G 28^{\top}$ from its close strains. The detailed physiological and biochemical characteristics of strain $\mathrm{RG}^{\mathrm{T}} 28^{\top}$ are summarized in the species description and characteristics that differentiated strain $\mathrm{RG}^{\mathrm{T}} 8^{\top}$ from its closest related type strains are listed in Table 1. 


\section{Chemotaxonomic analysis}

The whole-cell fatty acid profile of strain $\mathrm{RG}_{28}{ }^{\top}$ contained large amounts of $\mathrm{C}_{16: 0}(25.5 \%)$, iso- $\mathrm{C}_{15: 0 \&}(26.4 \%)$ and anteiso$\mathrm{C}_{15: 0 \&}(33.4 \%)$.\& A comparison of strain $\mathrm{RG}_{28}{ }^{\mathrm{T}}$ with closely related members of the genus\& Gottfriedia is presented in Table S2. Strain $\mathrm{RG} 8^{\top}$ had a similar fatty acid profile to\& $G$. acidiceleris KEMB $1602-188^{\top}$, \& G. solisilvae DSM $100485^{\top}$

and\& G. luciferensis KEMB 7305-013 ${ }^{\top}$, but the absence of $\mathrm{C}_{18: 0 \&}$ and iso- $\mathrm{C}_{13: 0 \text { \& }}$ in strain $\mathrm{RG}_{28}{ }^{\top}$ distinguish it from its close relatives. The peptidodoglycan of strain $\mathrm{RG}_{28}{ }^{\top}$ contained meso-DAP as the diagnostic diamino acid. The predominant menaquinone was MK-7 (57\%), followed by MK-6 (43\%). The quinone and peptidoglycan diamino acid of strain RG28 ${ }^{\top}$ as found in all known members of the genus\& Gottfriedia.\& However, strain RG28 ${ }^{\top}$ could be distinguished from the reference strains with the proportions of MK-7 and MK-6. In addition,\& G. acidiceleris CBD $119^{\top}$ has MK-8, which is not found in strain $\mathrm{RG}_{2}{ }^{\top}$ and other two reference strains, which clearly differentiates them from each other (Table 2).\& The polar lipid profile of strain $R 28^{\top}$ consist of diphosphatidylglycerol (DPG), phosphatidylethanolamine (PE), phosphatidylglycerol (PG) , four unidentified aminophosphoglycolipids (APGL1-4), four unidentified aminophospholipids (APL1-4), two unidentified glycolipids (GL1-2), one unidentified aminoglycolipid (AGL) and four unidentified lipids (L1-4) (Fig. S7). The major polar lipid profile was same with other three reference strains however the presence of other minor lipids distinguish the strain $\mathrm{RG}_{28}^{\top}$ from other closely related strains (Pan et al. 2017).

\section{Indole acetic acid (IAA) production and quantification}

Change in color showed that strain $\mathrm{RG}^{2} 8^{\top}$ and its reference strains $G$. acidiceleris KEMB 1602-188 ${ }^{\top}$, G. solisilvae DSM $100485^{\top}$ and $G$. Iuciferensis KEMB 7305-013 ${ }^{\top}$ showed the ability to synthesize IAA only in the presence of the precursor $L^{-}$ tryptophan and could produce 40.5, 55.2, 56.8 and $50.5 \mu \mathrm{g} / \mathrm{ml} \mathrm{IAA}$, respectively (Fig. 3).\& To the best of our knowledge, no reports are available for plant growth activities of genus\& Gottfriedia so far, in this study we found that all strain of genus\& Gottfriedia including novel strain $\mathrm{RG}^{2} 8^{\top}$ were able to produce IAA in sufficient amounts.\& Genome annotation also revealed the number of genes associated with\& tryptophan biosynthesis which is consistent with our results which\& suggest a potential use of\& Gottfriedia species as\& biofertilizer.

\section{Taxonomic conclusion}

Phylogenetic and phylogenomic analysis indicated that the strain $\mathrm{RG}_{2}{ }^{\top}$ formed a different cluster with the three members of genus\& Gottfriedia\& with high topology. Based on the above polyphasic taxonomic analysis, strain RG28 ${ }^{\top}$ was confirmed as a novel species in the genus\& Gottfriedia. Therefore, the name\& Gottfriedia endophyticus sp. nov. is proposed.

\section{Description of Gottfriedia endophyticus sp. nov.}

Gottfriedia endophyticus\& (en.do.phy'ti.cus. Gr. pref. Endo within; G. n. phyton plant; L. masc. suff. -icus adjectival suffix used with the sense of belonging to; N.L. masc. adj. endophyticus within plant, endophytic, pertaining to the original isolation from plant tissues).

Cells are short to long-rods, Gram-positive, aerobic, capable of forming ellipsoidal endospores and motile by flagella. Colonies on R2A agar are moist, flat, white and undulate in margins after three days of incubation at $30^{\circ} \mathrm{C}$. \& Growth occurs at $10-50^{\circ} \mathrm{C} \&$ (optimum, $30^{\circ} \mathrm{C}$ ) and $\mathrm{pH}$ of $5.0-10.0$ (optimum, $\mathrm{pH} 7.0$ ) and tolerates upto $5.0 \% \mathrm{NaCl}$. $\mathrm{NaCl}$ is not required for growth. Cells were positive for hydrolysis of casein, starch, CM-cellulose and Tween 80 but negative for chitin hydrolysis. Cells are positive for catalase and negative for oxidase activity.\& According to the API ZYM system, cells were positive for alkaline phosphatase, esterase (C4), esterase lipase (C8), leucine arylamidase, $\alpha$-chymotrypsin, acid phosphatase, naphtol-AS-BI-phosphohydrolase, $\beta$-glucuronidase, $\beta$-glucosidase. In the API 20NE system, all phenotypic 
characteristics are negative except for indole production, arginine dihydrolase, esculin hydrolysis and $\beta$-galactosidase. In $50 \mathrm{CH}$, following compounds are utilized as sole source of carbon and energy: $D$-ribose, ${ }_{D}$-glucose, $\mathrm{N}$-acetylglucosamine,

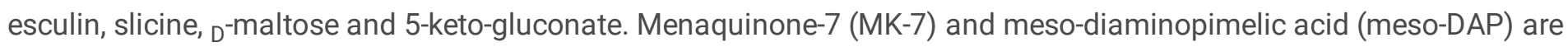
the major respiratory quinone and the diagnostic amino acid of the cell-wall peptidoglycan, respectively.\& The main components of the whole-cell fatty acids $(10 \%)$ are $\& C_{16: 0}$, iso- $C_{15: 0}$ and anteiso- $C_{15: 0 . \&}$ The major polar lipids consisted of phosphatidylethanolamine, diphosphatidylglycerol, phosphatidylglycerol, four unidentified aminophosphoglycolipids, four unidentified aminophospholipids, two unidentified glycolipids, one unidentified aminoglycolipid and four unidentified lipids.\& \& \& \& \& \&

The type strain is RG28 ${ }^{\top \&}\left(=K C T C 43327^{\top}=\right.$ TBRC $\left.15151^{\top}\right)$ which was isolated from the roots of rice plant collected from Goyang, South Korea. The DNA G+C content of the type strain is 33.5\%. The GenBank accession number for the 16S rRNA gene sequence is MW386408, and the genome accession number is JAGIYQ000000000.\&

\section{Abbreviations}

ANI, average nucleotide identity; $\mathrm{NJ}$, neighbour joining; $\mathrm{ML}$, maximum-likelihood; $\mathrm{ME}$, minimum-evolution; MP, maximumparsimony; KEMB, Korean Environmental Microorganisms Bank; DSMZ, Deutsche Sammlung von Mikroorganismen und Zellkulturen; IAA, indole acetic acid.

\section{Declarations}

\section{Funding}

This work was supported by the National Institute of Biological Resources (NIBR) grant, funded by the Ministry of Environment (MOE) of the Republic of Korea (NIBR202002203), and by the National Research Foundation of Korea (NRF) grant funded by the Korea government (MSIT) (2020R1F1A1072647).

\section{Conflicts of interest}

All the authors declare that there is no conflict of interest.

\section{Authors' contributions}

GC isolated the bacterium, designed the study, performed the phenotypic and biochemical characterization, and wrote the original draft; IK helped with the analysis of taxonomic data; TS designed and supervised the study, and edited the original draft.

\section{Ethics approval}

This study does not describe any experimental work related to human.

\section{References}

1. Blin K, Shaw S, Steinke K et al (2019) antiSMASH 5.0: updates to the secondary metabolite genome mining pipeline.Nucleic Acids Res47:W81-W87

2. Chhetri G, Kim J, Kim H et al (2019) Pontibacter oryzae sp. nov., a carotenoid-producing species isolated from a rice paddy field. Antonie Van Leeuwenhoek 112:1705-1713

3. Chhetri G, Kim J, Kim I, Kim H et al (2020) Adhaeribacter rhizoryzae sp. nov., a fibrillar matrix producing bacterium isolated from the rhizosphere of rice plant. Int J Syst Evol Microbiol 70:5382-5388 
4. Chhetri G, Kim J, Kim I, Kang M et al (2021a) Flavobacterium baculatum sp. nov., a carotenoid and flexirubin-type pigment producing species isolated from flooded paddy field. Int J Syst Evol Microbiol 71:004736

5. Chhetri G, Kim J, Kim I, Kang M, Seo T (2021b) Limnohabitans radicicola sp. nov., a slow-growing bacterium isolated from rhizosphere of rice plant and emended description of the genus Limnohabitans. Int J Syst Evol Microbiol 71:4957

6. Chun J, Oren A, Ventosa A, Christensen H, Arahal DR et al (2018) Proposed minimal standards for the use of genome data for the taxonomy of prokaryotes. Int J Syst Evol Microbiol 68:461-466

7. Collins MD, Jones D (1981) Distribution of isoprenoid quinone structural types in bacteria and their taxonomic implications. Microbiol Rev 45:316-354

8. Felsenstein J (1981) Evolutionary trees from DNA sequences: a maximum likelihood approach. J Mol Evol 17:368376

9. Felsenstein J (1985) Confidence limits on phylogenies: An approach using the bootstrap. Evolution 39:783-791

10. Fitch WM (1971) Toward defining the course of evolution: minimum change for a specific tree topology. Syst Zool 20:406-416

11. Gupta RS, Patel S, Saini N, Chen S (2020) Robust demarcation of 17 distinct Bacillus species clades, proposed as novel Bacillaceae genera, by phylogenomics and comparative genomic analyses: description of Robertmurraya kyonggiensis sp. nov. and proposal for an emended genus Bacillus limiting it only to the members of the Subtilis and Cereus clades of species. Int J Syst Evol Microbiol 70:5753-5798

12. Goris J, Konstantinidis KT, Klappenbach JA, Coenye T, Vandamme P et al (2007) DNA-DNA hybridization values and their relationship to whole-genome sequence similarities. Int J Syst Evol Microbiol 57:81-91

13. Jiang Lingmin JW, Yong L, Zhun L, Mi-Kyung et al (2021) Peribacillus faecalis sp. nov., a moderately halophilic bacterium isolated from the faeces of a cow. Int J Syst Evol Microbiol 71:004721

14. Kim OS, Cho YJ, Lee K, Yoon SH, Kim M et al (2012) Introducing EzTaxon-e: a prokaryotic 16S rRNA gene sequence database with phylotypes that represent uncultured species. Int J Syst Evol Microbial 62:716-721

15. Kim I, Chhetri G, Kim J, Seo T (2019) Amnibacterium setariae sp. nov., an endophytic actinobacterium isolated from dried foxtail. Antonie Van Leeuwenhoek 112:1731-1738

16. Kim H, Chhetri G, Kim J, Kang M, Seo T (2020) Lewinella aurantiaca sp. nov., a carotenoid pigment-producing bacterium isolated from surface seawater. Int J Syst Evol Microbiol 70:6180-6187

17. Kim J, Chhetri G, Kim I, Kim H et al (2020) Methylobacterium terrae sp. nov., a radiation-resistant bacterium isolated from gamma ray-irradiated soil. J Microbiol 959:966

18. Komagata K, Suzuki KI (1987) Lipid and cell-wall analysis in bacterial systematics. Methods Microbiol 19:161205

19. Kumar S, Stecher G, Tamura K (2016) Mega7: molecular evolutionary genetics analysis version 7.0 for bigger datasets. Mol Biol Evol 33:1870-1874

20. Kuykendall LD, Roy MA, O'Neill JJ, Devine TE (1988) Fatty acids, antibiotic resistance and deoxyribonucleic acid homology groups of Bradyrhizobium japonicum. Int J Syst Evol Microbiol 38:358-361

21. Logan NA, Lebbe L, Verhelst A, Goris J et al (2002) Bacillus luciferensis sp. nov., from volcanic soil on Candlemas Island, South Sandwich archipelago.Int. J. Syst. Evol. Microbiol52,1985-9

22. Meier-Kolthoff JP, Auch AF, Klenk HP, Göker M (2013) Genome sequence-based species delimitation with confidence intervals and improved distance functions. BMC Bioinformatics 14:60

23. Minnikin DE, O'Donnell AG, Goodfellow M, Alderson G, Athalye M et al (1984) An integrated procedure for the extraction of bacterial isoprenoid quinones and polar lipids. J Microbiol Methods 2:233-241

24. Pan T, He H, Wang X, Shen Y, Zhao J, Yan K et al (2017) Bacillus solisilvae sp. nov., isolated from forest soil. Int J Syst Evol Microbiol 67:4449-4455 
25. Peak KK, Duncan KE, Veguilla W, Luna VA, King DS et al (2007) Bacillus acidiceler sp. nov., isolated from a forensic specimen, containing Bacillus anthracis pX02 genes. Int J Syst Evol Microbiol 57:2031-2036

26. Na SI, Kim YO, Yoon SH, Ha SM, Baek I et al (2018) UBCG: up-to-date bacterial core gene set and pipeline for phylogenomic tree reconstruction. J Microbiol 56:280-285

27. Rai M, Varma A (2005) Arbuscular Mycorrhiza-like Biotechnological Potential of Piriformospora indica, Which Promotes the Growth of Adhatoda Vasica Nees. Electron J Biotechnol 8:1-6

28. Rzhetsky A, Nei M (1992) A simple method for estimating and testing minimum-evolution trees. Mol Biol Evol 9:945967

29. Saitou N, Nei M (1987) The neighbor-joining method: a new method for reconstructing phylogenetic trees. Mol Biol Evol 4:406-425

30. Smibert RM, Krieg NR (1994) Phenotypic Characterization. In: Gerhardt, P., Murray, R.G.E., Wood, W.A. and Krieg, N.R., (Eds). Methods for General and Molecular Bacteriology. American Society for Microbiology, Washington DC 607-654

31. Tatusova T, DiCuccio M, Badretdin A, Chetvernin V, Nawrocki EP et al (2016) NCBI prokaryotic genome annotation pipeline. Nucleic Acids Res 44:6614-6624

32. Thompson J, Gibson TJ, Plewniak F, Jeanmougin F, Higgins DG (1997) The CLUSTAL_X windows interface: flexible strategies for multiple sequence alignment aided by quality analysis tools. Nucleic Acids Res 25:4876-4882

33. Vandeputte O, Oden S, Mol A, Vereecke D, Goethals K et al (2005) Biosynthesis of Auxin by the Gram-positive Phytopathogen Rhodococcus fascians Is Controlled by Compounds Specific to Infected Plant Tissues. Appl Environ Microbiol 71:1169-1177

34. Xu L, Dong Z, Fang L, Luo Y, Wei Z et al (2019) OrthoVenn2: a web server for whole-genome comparison and annotation of orthologous clusters across multiple species. Nucleic Acids Res 47:W52-W58

35. Yoon SH, Ha SM, Lim J, Kwon S, Chun J (2017) A large-scale evaluation of algorithms to calculate average nucleotide identity. Antonie Van Leeuwenhoek 110:1281-1286

\section{Tables}

Table 1. Presence of genes associated with IAA and siderophore in genomes of strain $R G 28^{\top}$ and its reference strains. 
Proteins

\section{Tryptophan}

\begin{tabular}{|c|c|c|c|c|}
\hline $\begin{array}{l}\text { Tryptophan synthase subunit beta } \\
\text { trpB }\end{array}$ & J5Y03_RS14090 & B6K90_RS09040 & CAB05_RS14505 & B7R67_RS11880 \\
\hline Tryptophan-tRNA ligase trpS & J5Y03_RS05225 & B6K90_RS07255 & CAB05_RS11475 & B7R67_RS00505 \\
\hline Tryptophan 2,3-dioxygenase & J5Y03_RS10820 & B6K90_RS19860 & CAB05_RS13600 & B7R67_RS21350 \\
\hline $\begin{array}{l}\text { Tryptophan synthase subunit alpha } \\
\text { trpA }\end{array}$ & - & B6K90_RS09035 & CAB05_RS14500 & B7R67_RS11885 \\
\hline N-methyl-L-tryptophan oxidase solA & - & B6K90_RS14755 & - & - \\
\hline \multirow[t]{2}{*}{ Tryptophan-rich sensory protein } & - & \multirow[t]{2}{*}{ B6K90_RS15130 } & \multirow[t]{2}{*}{ CAB05_RS10035 } & B7R67_RS00150 \\
\hline & - & & & B7R67_RS21420 \\
\hline $\begin{array}{l}\text { Anthranilate } \\
\text { phosphoribosyltransferase trpD }\end{array}$ & - & B6K90_RS09055 & CAB05_RS14520 & B7R67_RS11865 \\
\hline $\begin{array}{l}\text { Anthranilate synthase component I } \\
\text { trpE }\end{array}$ & J5Y03_RS18995 & B6K90_RS09065 & CAB05_RS14530 & B7R67_RS02035 \\
\hline $\begin{array}{l}\text { Aminodeoxychorismate/anthranilate } \\
\text { synthase component II trpG }\end{array}$ & - & B6K90_RS09060 & CAB05_RS14525 & - \\
\hline \multicolumn{5}{|l|}{ Indole } \\
\hline $\begin{array}{l}\text { Indole-3-glycerol phosphate } \\
\text { synthase trpC }\end{array}$ & - & B6K90_RS09050 & CAB05_RS14515 & B7R67_RS11870 \\
\hline \multicolumn{5}{|l|}{ Siderophore } \\
\hline \multirow{2}{*}{$\begin{array}{l}\text { Iron-siderophore ABC transporter } \\
\text { substrate-binding protein }\end{array}$} & \multirow[t]{2}{*}{-} & B6K90_RS18340 & CAB05_RS13705 & \multirow[t]{2}{*}{ B7R67_RS14995 } \\
\hline & & B6K90_RS19730 & CAB05_RS10175 & \\
\hline
\end{tabular}

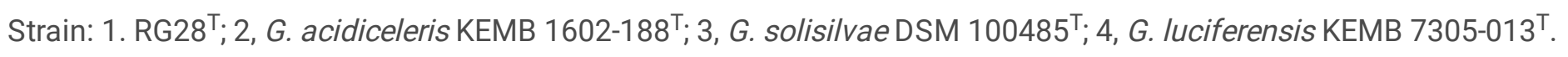

Table 2. Physiological and biochemical characteristics of strain $\mathrm{RG}_{2}{ }^{\top}$ and closely related type strains of the genus Gottfriedia. 


\begin{tabular}{lllll}
\hline Characteristics & $\mathbf{1}$ & $\mathbf{2}$ & $\mathbf{3}$ & $\mathbf{4}$ \\
\hline Isolation source & Roots & Forensic speciemen & Forest soil & Volcanic soil \\
\hline Cell morphology & $\begin{array}{l}\text { Rods } \\
\text { occurring } \\
\text { singly or in } \\
\text { pairs }\end{array}$ & $\begin{array}{l}\text { Rods occurring in pairs or short } \\
\text { chains with branches* }\end{array}$ & $\begin{array}{l}\text { Rods occurring } \\
\text { singly or in } \\
\text { pairs* }\end{array}$ & $\begin{array}{l}\text { Rods occurring } \\
\text { singly or in } \\
\text { pairs* }\end{array}$ \\
\hline Colony colour & Cream & Cream to pearly grey & Cream & Creamy-grey \\
\hline Swollen sporangia & + & + & + & - \\
\hline Motility & + & - & + & + \\
\hline Catalase/oxidase & $+/-$ & $+/+$ & $+/-$ & $+/-$ \\
\hline $\begin{array}{l}\text { Temperature range } \\
\text { for growth }{ }^{\circ} \text { C) }\end{array}$ & $10-50$ & $15-45$ & $15-40$ & $15-45$ \\
\hline pH range for growth & $5.0-10.0$ & $6.0-8.0$ & $6.0-8.0$ & $5.0-9.0$ \\
\hline NaCl (\%) tolerance & $0-5$ & $0-3$ & $0-4$ & $0-3$ \\
\hline
\end{tabular}

\section{Hydrolysis of :}

\begin{tabular}{lcccc} 
Gelatin & - & + & - & + \\
\hline Urea & - & + & - & - \\
Casein & + & + & - & + \\
Starch & + & - & + & + \\
\hline CM-cellulose & + & - & + & + \\
\hline Tween 80 & + & - & +
\end{tabular}

\section{Enzyme activity:}

\begin{tabular}{|c|c|c|c|c|}
\hline Esterase Lipase (C8) & + & - & - & + \\
\hline Lipase (C14) & - & + & + & - \\
\hline Valline arylamidase & - & + & + & - \\
\hline Cystine arylamidase & - & + & + & + \\
\hline$a$-chymotrypsin & + & - & + & + \\
\hline$\alpha$-galactosidase & - & - & - & + \\
\hline $\begin{array}{l}\mathrm{N} \text {-acetyl- } \beta \text { - } \\
\text { glucosaminidase }\end{array}$ & - & + & - & - \\
\hline
\end{tabular}

\section{API 20NE:}

$\begin{array}{lllll}\text { Glucose fermentation } & - & + & + & - \\ \beta \text {-galactosidase } & + & - & + & + \\ \text { L-arabinose } & - & + & + & -\end{array}$

Acid production from (API $50 \mathrm{CH}$ ): 


\begin{tabular}{|c|c|c|c|c|}
\hline L-arabinose & - & + & + & + \\
\hline$D^{-x y l o s e}$ & - & + & - & - \\
\hline$L^{-x y l o s e}$ & - & + & - & - \\
\hline D-glucose & + & - & - & + \\
\hline L-rhamnose & - & + & + & + \\
\hline Inositol & + & - & - & + \\
\hline $\begin{array}{l}\text { Methyl- }^{-}{ }^{-} \\
\text {mannopyranoside }\end{array}$ & - & + & - & - \\
\hline $\mathrm{D}^{\text {-trehalose }}$ & - & + & + & + \\
\hline Glycogen & - & + & + & - \\
\hline Xylitol & - & + & + & + \\
\hline D-turanose & + & + & - & - \\
\hline Menaquinone types & $\begin{array}{l}\text { MK-7 (57\%), } \\
\text { MK-6 (43\%) }\end{array}$ & $\begin{array}{l}\text { MK-7 (53\%), MK-6 (31\%), MK-8 (16 } \\
\%)\end{array}$ & $\begin{array}{l}\text { MK-7 (54\%), } \\
\text { MK-6 (46\%) }\end{array}$ & $\begin{array}{l}\text { MK-6 (64\%), } \\
\text { MK-7 (36\%) }\end{array}$ \\
\hline DNA G+C content (\%) & 33.5 & 32.8 & 33 & 32.8 \\
\hline
\end{tabular}

Strain: 1. RG28 ; 2, G. acidiceleris KEMB 1602-188'T, 3, G. solisilvae DSM 100485' ; 4, G. luciferensis KEMB 7305-013'. Data were taken from this study unless otherwise indicated. +, Positive; -, negative. Data for DNA G+C content (\%) were covered from NCBI, whole genome annotation.

*Data taken from Peak et al. 2007.

\section{Figures}




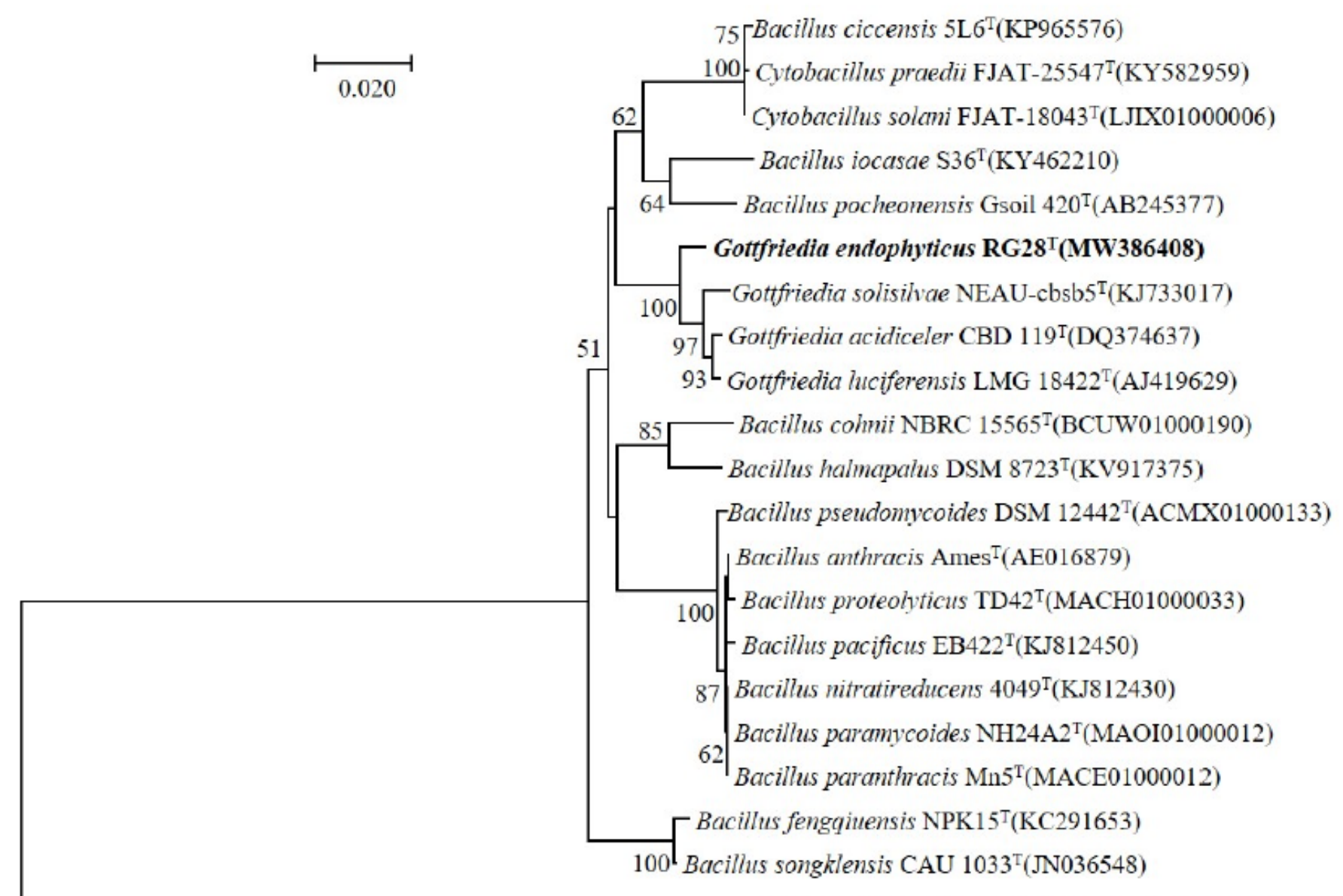

Persicobacter diffluens NBRC 15940T(AB260929)

\section{Figure 1}

Neighbour-joining tree based on 16S rRNA gene sequences showing the relationship between strain RG28 ${ }^{\top}$ and related species. Persicobacter diffluens NBRC $15940^{\top}$ (AB260929) was used as an out-group. Bootstrap values (based on 1000 replications) greater than $50 \%$ are shown at branch points. Bar, 0.020 substitutions per nucleotide position. 

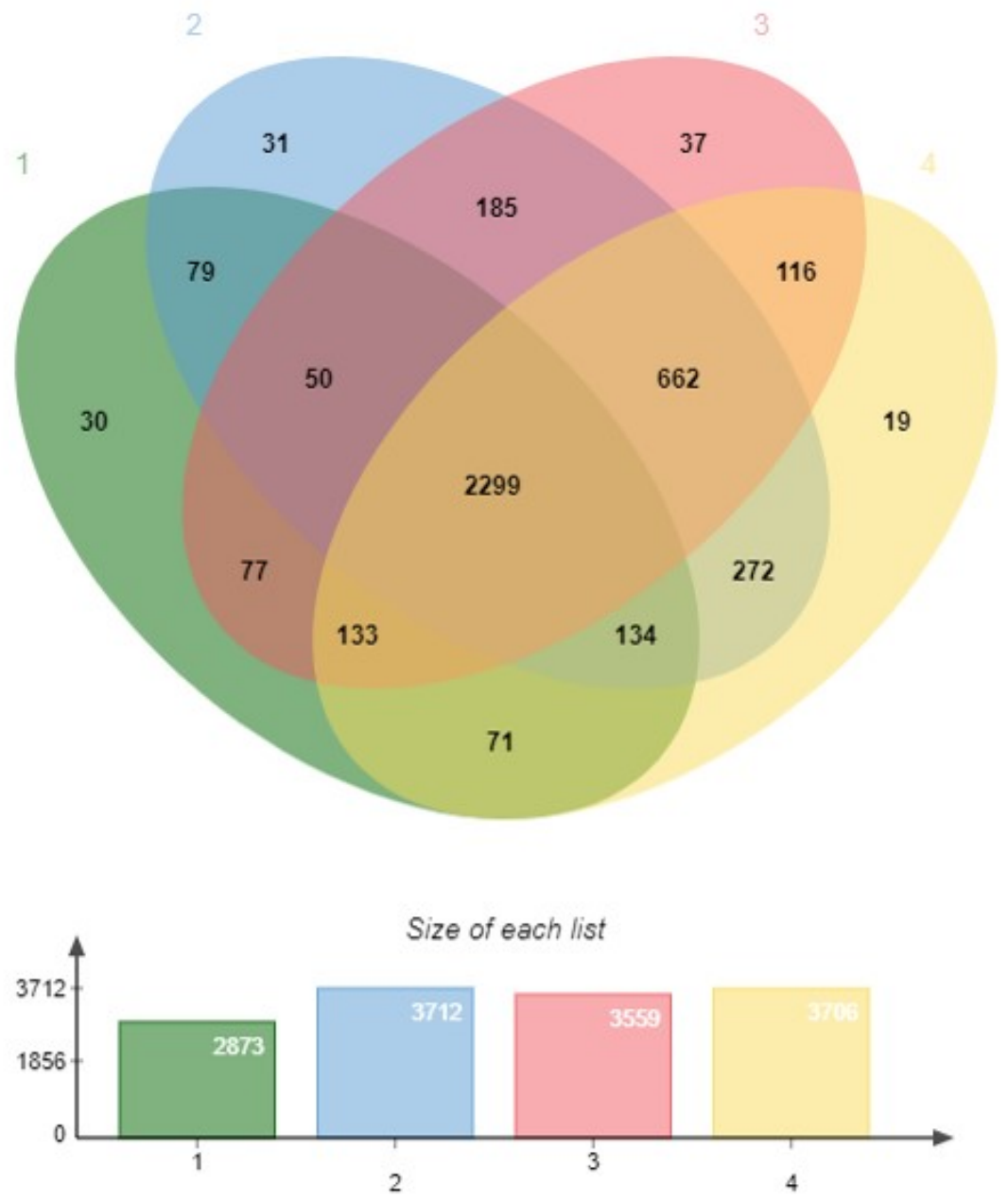

Number of elements: specific (1) or shared by $2,3, \ldots$ lists

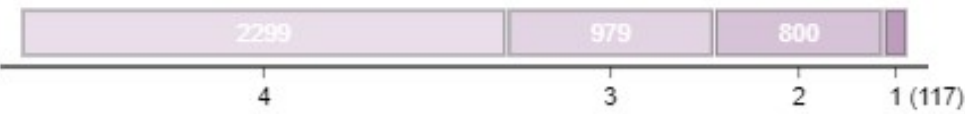

\section{Figure 2}

Venn diagram of whole-genome orthologous genes in $\mathrm{RG}_{28}{ }^{\top}$ and three reference strains. The numbers in the diagram indicate overlapped conserved genes or non-overlapped unique genes in each species. Strain: $1, \mathrm{RG}_{2}^{\mathrm{T}} ;{ }^{\mathrm{T}}, \mathrm{G}$. acidiceleris

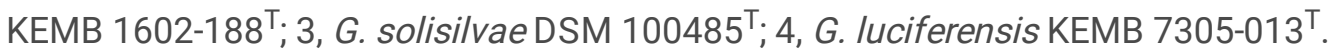




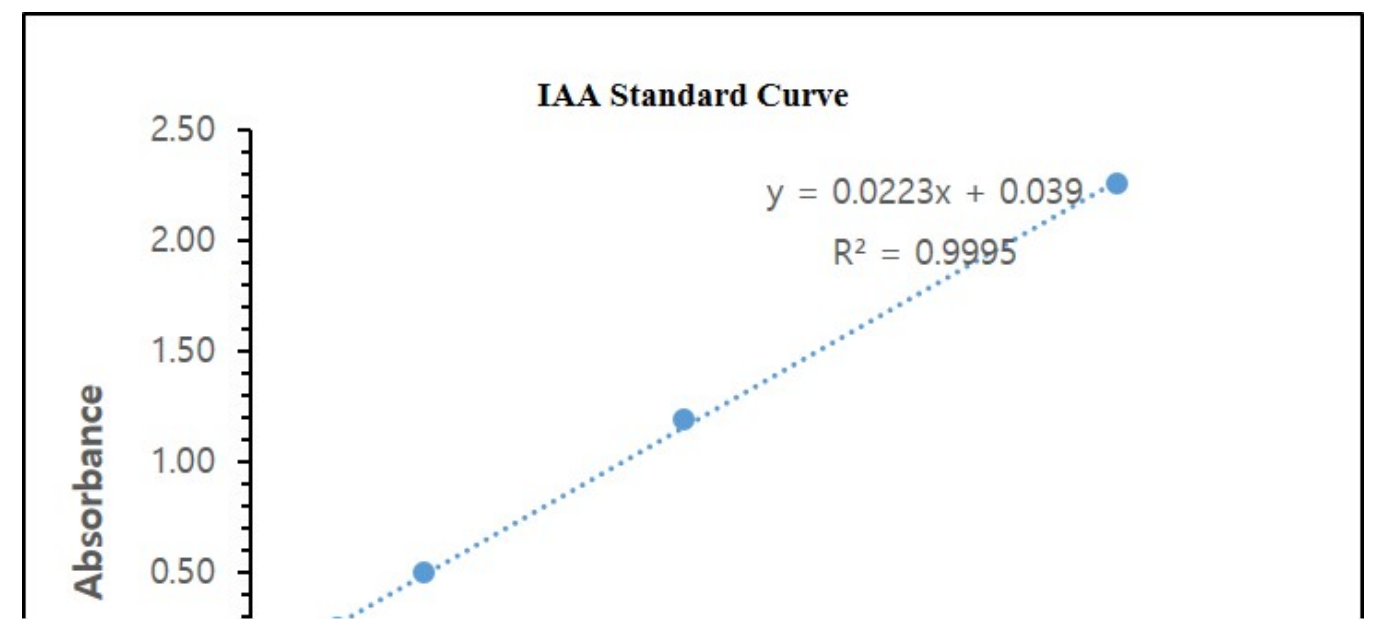

\section{Figure 3}

Standard curve and graph of the test results on the production of IAA. All strains were grown on R2A media amended with

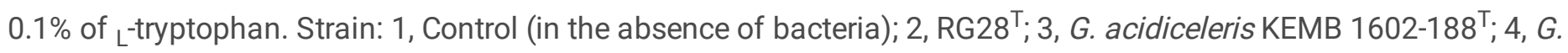
solisilvae DSM $100485^{\top} ;$ 5, G. Iuciferensis KEMB 7305-013'T.

\section{Supplementary Files}

This is a list of supplementary files associated with this preprint. Click to download.

- Supplementarymaterials.docx 